\title{
KEPASTIAN HUKUM KEPEMILIKAN TANAH ULAYAT KAUM ADAT BADUY
}

\author{
Eliana \\ Fakultas Hukum Universitas Pamulang \\ doseno1344@unpam.ac.id
}

\begin{abstract}
Baduy people are the subject of ulayat rights, it is the communities of adat law which are still communal, usually there are members of adat as community members, there is a chairman and sometimes there are Adat Elders, every communities of adat law jointly has the rights that are civilization over the territory of the adat community The ulayat land ownership of the Baduy people is interesting to be researched. What must be fulfilled in ownership, how the land transition takes shape, what is the form of legal certainty over the ownership of the ulayat communal land of the Baduy. Because at this time the land is a necessity for all the people of Indonesia is no exception for the Baduy community because the land functions as a means or a place to live for people every day so it becomes a need that must be strengthened with proof of ownership in the form of land certificates. Land as a requirement must be certified is the Basic Agrarian Law Articlet 19 paragraph (1) that to guarantee legal certainty by the government, land registration is carried out throughout the territory of the Republic of Indonesia according to the provisions regulated by government regulations.
\end{abstract}

Key words: legal certainty, ulayat land, Baduy

\begin{abstract}
ABSTRAK
Kaum Adat Baduy adalah Subyek dari hak ulayat yaitu masyarakat hukum adat yang masih bersifat komunal, biasanya ada anggota adat sebagai masayarakatnya, ada Ketua dan kadang ada para Tetua Adat, setiap masyarakat hukum adat secara bersama-sama memiliki hak yang bersifat keperdataan atas wilayah kaum adatnya. Kepemilikan tanah ulayat kaum adat Bady menarik diteliti, Apa saja yang harus dipenuhi dalam kepemilikan, bagaimana bentuk peralihan Tanah, bagaimana bentuk kepastian hukum terhadap kepemilikan tanah adat kaum kommunal adat Baduy. Karena saat ini tanah menjadi kebutuhan seluruh rakyat Indonesia tidak terkecuali bagi kaum masyarakat Baduy karena tanah berfungsi sebagai sarana atau tempat tinggal bagi manusia sehari hari sehingga menjadi kebutuhan yang harus dikuatkan dengan bukti kepemilikan dalam bentuk sertipikat tanah. Tanah sebagai kebutuhan tersebut harus disertipikatkan adalah Undang-Undang Pokok Agraria Pasal 19 ayat (1) bahwa untuk menjamin kepastian hukum oleh pemerintah diadakan pendaftaran tanah diseluruh wilayah Republik Indonesia menurut ketentuan-ketentuan yang diatur dengan peraturan pemerintah.
\end{abstract}

\section{Kata kunci: Kepastian Hukum, Tanah Ulayat, Kaum adat Baduy}




\section{PENDAHULUAN}

Sifat komunalistik menunjukan adanya hak bersama para anggota disebut hak ulayat, tanah ulayat merupakan tanah kepunyaan bersama yang diyakini sebagai karunia suatu kekuatan gaib atau peninggalan nenek moyang kepada kelompok yang merupakan masyarakat hukum adat, sebagai unsur pendukung utama bagi kehidupan dan penghidupan kelompok tersebut sepanjang masa (Budi Harsono, 2008: 181).

Dalam hukum adat yang dapat mempunyai hak atas tanah bukan hanya orang perseorangan, melainkan juga persekutuan hukum. Hak persekutuan hukum atas tanah ini biasanya disebut hak pertuanan atau hak ulayat, Menurut hukum adat yang dapat mempunyai hak atas tanah bukan hanya orang perseorangan, melainkan juga persekutuan hukum. Hak persekutuan hukum atas tanah ini biasanya disebut hak pertuanan atau hak ulayat. (H.A.M Effendy,1990:4).

Hukum tanah mengatur tentang hak untuk memperoleh dan memindahkan hak atas tanah, seperti hak menjual tanah, menghadiahkan tanah, menghibahkan tanah, menyediakan tanah untuk badan hukum adat (wakaf, yayasan) dan sebagainya. Peralihan diatur dalam ketentuan dalam Pasal 37 ayat (1) Peraturan Pemerintah Nomor 24 tahun 1997 bahwa peralihan hak atas tanah dan hak milik atas satuan rumah susun melalui jual beli, tukar menukar, hibah, pemasukan dalam perusahaan dan perbuatan hukum pemindahan hak lainnya kecuali pemindahan hak melalui lelang, hanya dapat didaftarkan jika dibuktikan dengan akta yang dibuat oleh PPAT yang berwenang menurut ketentuan peraturan perundang-undangan yang berlaku (Waskito Hadi Arnowo,2015:117).

Istilah hak ulayat disebut oleh van Vollen Hoven sebagai beschikkingrecht, oleh Soepomo disebut Hak Pertuanan,
Teer Haar mengistilahkannya sebagai Hak Pertuanan, dan masyarakat minang menyebutnya dengan kosa kata ulayat (Purnadi Purwacaraka dan Ridwan Halim, 1983:25-26). Di Provinsi Banten masyarakat kaum Baduy kaum kommunal yang masih ada di daerah Banten lebak kecamatan Kenekes yang terikat oleh tatanan hukum adatnya sebagai warga suatu persekutuan hukum yang mengakui dan menerapkan ketentuan persekutuan dalam kehidupan sehari-hari, memiliki wilayah serta memiliki hubungan dengan wilayahnya tersebut, hubungan kaum Baduy dengan wilayahnya perlu dilindungi, bagimana perlindungan atas hak ulayat Masyarakat Baduy tersebut dan bagaimanan kepastian hukum terhadap kepemilikan hak atas tanahnya menjadi menarik.

\section{METODE PENELITIAN}

Jenis penelitian ini menggunakan Metode Yuridis normative didukung oleh yuridis Empiris, Penelitian Hukum Normatif adalah penelitian hukum yang dilakukan dengan cara meneliti bahan pustaka atau data sekunder belaka (Soerjono Soekamto\&Sri Mamuji, 1985:40). Penelitian yuridis empiris hukum sebagai law in action, dideskripsikan sebagai gejala sosial dilapangan. Pendekatan yang digunakan pendekatan perundang-undangan dan pendekatan kasus sehingga antara aturanaturan dan kenyataan dapat diketahui kesinambungannya.

\section{PERMASALAHAN}

Untuk memberi arahan pada penulis dalam melakukan penelitian ini maka permasalahan yang diangkat adalah bagaimana bentuk kepastian hukum kepemilikan tanah kaum adat baduy dan bagaimana bentuk perlindungan hukum tanah ulayat kaum baduy apabila terjadi peralihan hak? 
PEMBAHASAN

\section{Bentuk Kepastian Hukum Kepemilikan Tanah Kaum Adat Baduy}

Tanah adat menurut pemerintah Hindia Belanda adalah tanah-tanah yang dipunyai rakyat dengan hak milik adat demikian juga tanah-tanah ulayat masyarakat kaum adat (tanpa bukti jelas tertulis) adalah tanah domein negara (Muchtar Wahid, 2008:16). Negara Indonesia adalah Negara Hukum, Undang-undang Dasar 1945 merupakan sumber hukum, dalam kaitan dengan hak milik ditetapkan pasal 28 huruf h ayat (4) bahwa "setiap orang berhak mempunyai hak milik pribadi dan hak milik tersebut tidak boleh diambil alih secara sewenang-wenang".

Untuk mengakomodasi macammacam hak yang berlaku ketika jaman sebelum Indonesia merdeka Peraturan Mentri Negara Agraria/Kepala Badan Pertanahan Nasional Nomor 3 Tahun 1997 dilakukan penyempurnaan terhadap tanda bukti hak dengan kretiria sebagai berikut :

a. Surat Pajak hasil bumi/Landrete atau Verponding Indonesia yang dikeluarkan sebelum Peraturan Pemerintah Nomor 10 Tahun 1961 dinyatakan berlaku di daerah yang bersangkutan

b. Surat-surat asli jual beli, hibah atau tukar menukar yang dibuat dihadapan dan disaksikan Kepala Desa/Adat sebelum Peraturan Pemerintah Nomor 24 Tahun1997

c. Surat Keputusan Pemberian hak oleh instansi yang berwenang

d. Surat tanda bukti hak milik ayang diterbitkan berdasarkan Peraturan Swapraja.

Kepastian hukum hanya bisa dijawab secara normatif bukan sosiologi, kepastian hukum secara normatif ketika suatu peraturan dibuat dan diundangkan secara pasti karena mengatur secara jelas dan logis. Jelas dalam artian tidak menimulkan keragu-raguan (multi-tafsir) dan logis dalam artian ia menjadi suatu sistem norma dengan norma lain sehingga tidak berbenturan atau menimbulkan konflik norma. Konflik norma yang ditimbulkan dari ketidak pastian aturan dapat berbentuk konsestasi norma, reduksi norma atau distorsi norma, kepastian hukum menujukan kepada pemberlaku hukum yang jelas, tetap, konsisten dan konsekuen yang pelaksanaannya tidak dapat dipengaruhi oleh keadaan-keadaan yang sifatnya subjektif (Jarot Widya Muliawan, 2016:12).

Bentuk kepastian hukum atas kepemilikan tanah kaum adat baduy implementasi dari Peraturan Pemerintah Nomor 24 tahun 1997 Tentang Pendaftaran Tanah dan pengembangan Peraturan Pemerintah Nomor 10 tahun 1961, sebagaimana pendapat dari Supriyadi, Kepala Seksi BPN Lebak yang mengemukakan bahwa :

1. Kesepaktan Penetapan Batas Bidang Tanah Ulayat

Penunjukan batas oleh pemegang hak yang bersangkutan dan dan sedapat mungkin disetujui oleh pemegang hak atas tanah yang berbatasan, dengan ketentuan persetujuan tersebut dituangkan dalam suatu berita acara yang ditandatangani oleh yang memberikan persetujuan

2. Pembuktina Hak Dengan Penguasaan Fisik

Pembuktian hak penguasaan tanah kaum adat baduy telah diteliti dan sampai saat ini tidak terdaftar secara administratif di Kantor Pertanahan Kabupaten Lebak, baik atas nama Ketua Adat, atau salah satu dari masyarakat kaum komunal adat Baduy. Mereka tidak mengenl kepemilikan hak atas tanah secara individu, atau mengatas namakan kepemilikan tanah pada ketua adatnya. Masyarakat Komunal adat Baduy meyakini hak atas 
tanah adalah karunia Tuhan yang langsung mereka peroleh untuk dimanfaatkan bersama-sama demi kelangsungan hidupnyasebagai perwakilan pemilik alam.

Berbeda dengan masyarakat Baduy yang telah keluar dari kelompok kaum adat Baduy (dinamkan Baduy Luar) telah berbaur dengan masyarakat Kenekes, hidupnya diluar wilayah Tanah ulayat Masyarakat Adat Baduy, berlaku ketentuan yang sama dengan masyarakat Banten lainnya, apabila pemegang hak tidak dapat menyediakan bukti kepemilikan tanahnya baik berupa bukti tertulis maupun bentuk lain yang dapat dipercaya, maka pembukuan hak dapat dilakukan tidak berdasarkan kepemilikan akan tetapi berdasarkan bukti penguasaan fisik tanah, dengan syarat :

a. Pemohon telah menguasai secara nyata tanah selama 20 tahun;

b. Penguasaan tanah itu telah dilakukan dengan itikad baik;

c. Penguasaan itu tidak pernah diganggu gugat dan karena itu dianggap diakui dan dibenarkan masyarakat hukum adat atau desa/kelurahan;

d. Tanah tersebut tidak dalam sengketa;

e. Jika pernyataan tidak sesuai dengan kenyataan, bersedia dituntut di muka hakim secara pidana maupun perdata karena memberikan keterangan palsu.

Bentuk kepastian hukum terhadap Penguasaan Tanah Kaum Adat Baduy tidak pernah dibutuhkan oleh kalangan masyarakat ulayat adat Baduy, Pengukuhan dan pengakuan secara resmi bahwa Desa Kenekes merupakan tanah ulayat Masyarakat Baduy adalah Peraturan Daerah Kabupaten Lebak Nomor 32 Tahun 2001 tentang
Perlingungan atas Hak Ulayat Masyarakat Baduy.

Pengukuhan dicantumkan dalam Lembaran Daerah Kabupaten Lebak Nomor 65 seri D Tahun 2001 yang selanjutnya diperkuat dengan Surat keputusan Bupati Lebak Nomor 580/Kep.233/Huk/2002 tentang Penetapan Batas-Batas Detail Hak Ulayat Masyarakat Adat Baduy di Desa Kenekes Kecamatan Leuwidamar Kabupaten Lebak, Tanggal 16 Juli 2002 atas dasar hasil pengukuran dan pemetaan mengacu pada batas wilayah administratif, batasbatas khusus dan batas alam yang dilakukan oleh BPN Lebak.

Secara administrasi kepastian hukum terhadap bentuk kepemilikan Tanah kommunal adat Baduy terakomodasikan dengan pengukuran yang sudah dilakukan oleh BPN Lebak adalah bentuk perlindungan hukum terhadap hak ulayat tanah masyarakat kaum Adat Baduy yang dituangkan pemerintah Kecamatan Lebak dalam Peraturan Daerah Kabupaten Lebak Nomor 32 Tahun 2001 tentang Perlingungan atas Hak Ulayat Masyarakat Baduy.

Tanah ulayat masyarakat kaum Adat Baduy adalah 5.136, 58 Hektar yang terbagi menjadi dua bagian yaitu \pm 3.000 Hektar berupa hutan tutupan/lindung dan \pm 2.136, 58 Hektar merupakan tanah garapan dan pemukiman. Terdiri dari 59 Kampung, 3 Kampung yaitu Cibeo, Cikartawan dan Cikeusik adalah termasuk wilayah Baduy Dalam dan 56 Kamupung Lainnya adalah wilayah Baduy.

\section{Bentuk perlindungan hukum tanah ulayat kaum baduy apabila terjadi peralihan hak.}

Mengenai perlindungan hukum, sebagaimana Pasal 28 D ayat (1) UndangUndang Dasar 1945 perubahan ketiga yang menyatakan bahwa "setiap orang berhak atas pengakuan, jaminan 
perlindungan dan kepastian hukum yang adil serta perlakuan yang sama di hadapan hukum" jelas telah diamanatkan oleh konstitusi dan wajib untuk diterapkan pada setiap perumusan peraturan perundang-undangan.

Bentuk perlindungan hukum Status tanah ulayat milik kaum adat baduy apabila terjadi peralihan pertama status tanah ulayat tersebut sudah harus menjadi "tanah negara" terlebih dahulu. Tanah bekas ulayat merupakan tanah yang tidak dihaki lagi oleh masyarakat hukum adat, untuk itu berdasarkan UUPA tanah tersebut secara otomatis dikuasai langsung oleh negara. Dalam praktik administrasi digunakan sebutan tanah negara (apabila milik masyarakat adat baduy) dianggap tidak bersifat komunal lagi hingga hak ulayatnya menjadi hak milik negara yang kemudian dapat dimohon oleh siapa saja dan dapat diperalihkan menjadi hak perseorangan.

Kedua mengenai tata cara peralihan hak atas tanah negara menjadi hak milik diatur dalam Peraturan Menteri Negara Agraria/ Kepala Badan Pertanahan Nasional Nomor 9 Tahun 1999 Pasal 9 ayat (1) jo. Pasal 11 bahwa Permohonan Hak Milik atas tanah negara diajukan secara tertulis kepada Menteri melalui Kepala Kantor Pertanahan yang daerah kerjanya meliputi letak tanah yang bersangkutan. Permohonan tersebut memuat data yuridis (dapat berupa sertifikat, girik atau surat - surat bukti perolehan tanah lainnya serta diketahui data fisik (apabila ada) surat ukur, gambar situasi dan Ijin Mendirikan Bangunan. Ketentuan Pasal 58 UUPA mengakui masih berlakunya hak-hak ulayat maupun hak-hak lain sejenis yang tidak bertentangan dan selama belum diatur khusus oleh Pasal 3 UUPA sebagai berikut

1. Bahwa hak ulayat itu masih terdapat dalam masyarakat dan masih ada atau merupakan kenyataan hidup artinya hak ulayat itu masih berfungsi dalam masyarakat dan masih dipatuhi oleh masyarakat sebagai suatu lembaga dalam masyarakat.

2. Harus disesuaikan dengan kepentngan nasional artinya ada prinsip nasionalitas, (bandingkan dengan Pasal 5 UUPA) yaitu sungguhpun diketahui menurut hukum adat ada sejumlah justiabelnya menurut hukum adat masih berhak atas tanah hak-hak adat di daeraha asalnya namun karena mereka menjadi terdinding.

3. Harus disesuaikan dengan kepentingan negara.

4. Harus berdasarkan kepada persatuan bangsa artinya hak ulayat itu selama ini melayani hanya orang yang menjadi anggota suku itu saja dan orang luar sukunya hanya boleh mempunyai sesuatu hak setelah membayar suatu rekognisi (disuku Batak dinamakan Pago-pago). Dalam setiap konsep ini maka setiap warga Indonesia di manapun dia berada di wilayah Indonesia sama berhaknya dengan lain-lain suku bangsa untuk mempunyai hak-hak agraria.

5. Hak Ulayat itu untergeordnet kepada undang-undang maupun peraturan lainnya yang diterbitkan oleh pemerintah Indonesia. Dengan demikian biar hak ulayat itu adanya sebelum UUPA, namun kemudian harus seirama dan sejalan dan tunduk kepada etentuan-ketentuan umum yang dibuat untuknya dalam konteksnya keberlakuannya di Indonesia.

Dalam Konsideran Peraturan Daerah Kabupaten Lebak Nomor 32 Tahun 2001 Tanggal 13 Agustus 2001 disebutkan bahwa Masyarakat Baduy sebagai masyarakat adat yang terikat oleh tatanan hukum adatnya sebagai warga bersarna suatu persekutuan hukum yang mengakui dan menerapkan ketentuan persekutuan hukumnya dalam kehidupan 
sehari-hari. memiliki wilayah yang bersifat ulayat serta memiliki hubungan dengan wilayahnya tersebut. Kemudin bahwa Masyarakat Baduy dalam melakukan hubungan dengan wilayahnya diatur dan dibatasi pada wilayah ulayatnya, sehingga perlu dilindungi, untuk melakukan perlindungan atas hak ulayat Masyarakat Baduy perlu ditetapkan dan diatur dengan Peraturan Daerah Kabupaten Lebak.

$$
\text { Sehingga Pemerintah Daerah }
$$

Lebak dengan persetujuan Dewan Perwakilan Rakyat Daerah Kabupaten Lebak Menetapkan Peraturan Daerah Tentang Perlindungan Hak Atas Hak Ulayat Masyarakat Baduy, Dalam Peraturan Daerah ini, yang dimaksud dengan Pemerintah Daerah adalah Pemerintah Kabupaten Lebak, Bupati adalah Bupati Lebak, Perlindungan adalah suatu rangkaian kegiatan yang dilakukan oleh Pemerintah Daerah dan masyarakat dalam melindungi tatanan masyarakat Baduy dari upaya-upaya yang mengganggu/merusak yang berasal dari luar masyarakat Baduy.

Hak Ulayat adalah kewenangan yang menurut hukum adat dipunyai oleh masyarakat hukum adat tertentu atas wilayah tertentu yang merupakan lingkungan hidup para warganya untuk mengambil manfaat dari sumber daya alam, termasuk tanah, dalam wilayah tersebut, bagi kelangsungan hidup dan kehidupannya, yang timbul dari hubungan secara lahiriah dan batiniah turun temurun dan tidak terputus antara masyarakat hukum adat tersebut dengan wilayah yang bersangkutan.

Tanah Ulayat adalah bidang tanah yang di atasnya terdapat hak ulayat dari suatu masyarakat hukum adat tertentu, Mmsyarakat Baduy adalah masyarakat yang bertempat tinggal di Desa Kanekes Kedamatan Leuwidamar Kabupaten Lebak yang mempunyai ciri kebudayaan dan adat istiadat yang berbeda dengan masyarakat umum, Penggunaan Lahan adalah setiap upaya yang dilakukan baik oleh perorangan maupun oleh kelompok orang tertentu/badan yang berkaitan dengan pengusahaan lahan bagi peruntukkan pertanian, perkebunan, dan pemanfaatan hasil alam lainnya.

Peralihan tanah atas tanah ulayat kaum komunal adat Baduy atau atas nama Ketua Adat Baduy sampai saat ini belum pernah diketahui atau terdaftar di Kantor Pertanhaan karena peralihan tanah adat atas nama ketua adat baduy tidak pernah terjadi dan terdaftar di Kantor Pertanahan Kabupaten Lebak. Namun semua perbuatan hukum yang bertujuan memindahkan sebidang tanah kepada pihak lain wajib dilakukan di hadapan Pejabat Pembuat Akta Tanah (PPAT) yang bertugas membuat Akta, yang membuktikan terjadinya perbuatan hukum pemindahan hak tersebut, PPAT berfungsi sebagai pembantu Kepala Kantor Pertanahan, yang mana Kepala Kantor Pertanahan hanya akan melakukan perubahan data yuridis yang terdapat dalam Buku Tanah apabila ada perubahan didasarkan pada akta otentik yang dibuat oleh PPAT, Persyaratan dari pihak pembeli adalah bukti identitas diri berupa Kartu Tanda Penduduk (KTP), Kartu Keluarga (KK), Kartu Identitas wajib Pajak (NPWP);

Persyaratan dari pihak penjual terdiri dari:

a. Sertipikat asli HAT yang akan dijual atau alas hak seperti Girik/Leter C (bila belum bersertipikat);

b. Bukti identitas berupa kartu Tanda Penduduk (KTP), Kartu Keluarga (KK)/Surat Nikah, NPWP ;

c. Bukti Pembayaran Pajak Bumi dan Bangunan (PBB) yang terbaru;

d. Persetujuan istri atau suami bagi yang telah berkeluarga;

e. Surat Kuasa bila penjual diwakili oleh kuasa;

f. Surat bukti pelunasan Bea Perolehan Hak Atas Tanah dan Bangunan 
(BPHTB) sebagaimana yang telah diatur dalam Undang-Undang Nomor 21 Tahun 1997 tentang Bea Perolehan Hak Atas Tanah dan Bangunan sebagaimana telah diubah dengan Undang-Undang Nomor 20 Tahun 2000 Tentang Perubahan Atas Undang-Undang Nomor 21 Tahun 1997 Tentang Bea Perolehan Hak Atas Tanah dan Bangunan.

\section{PENUTUP}

\section{Kesimpulan}

Bentuk kepastian hukum kepemilikan tanah kaum adat baduy secara Hukum administrasi pertanahan telah melalui proses pengukuran yang dilakukan oleh Kantor Pertananahan Kabupaten Lebak dalam rangka inventarisasi kemudian diputuskan secara resmi tanah tersebut adalah hak ulayat masyarakat kaum Adat Baduy seluas 5.136, 58 Hektar yang terbagi menjadi dua bagian yaitu \pm 3.000 Hektar berupa hutan tutupan/lindung dan \pm 2.136, 58 Hektar merupakan tanah garapan dan pemukiman. Terdiri dari 59 Kampung, 3 Kampung yaitu Cibeo, Cikartawan dan Cikeusik adalah termasuk wilayah Baduy Dalam dan 56 Kampung Lainnya adalah wilayah Baduy dengan lahirnya Peraturan Daerah Kabupaten Lebak Nomor 32 Tahun 2001 tentang Perlingungan atas Hak Ulayat Masyarakat Baduy.

Pengukuhan dimasukkan dalam

Lembaran Daerah Kabupaten Lebak Nomor 65 seri D Tahun 2001 yang selanjutnya diperkuat dengan Surat keputusan (SK) Bupati Lebak Nomor 580/Kep.233/Huk/2002 tentang Penetapan Batas-Batas Detail Hak Ulayat Masyarakat Adat Baduy di Desa Kenekes Kecamatan Leuwidamar Kabupaten Lebak, Tanggal 16 Juli 2002 atas dasar hasil pengukuran dan pemetaan serta mengacu pada batas wilayah administratif, batas-batas khusus dan batas alam yang dilakukan oleh BPN.
Bentuk perlindungan hukum tanah ulayat kaum baduy apabila terjadi peralihan hak adalah dengan melibatkan PPAT karena semua perbuatan hukum yang bertujuan memindahkan sebidang tanah kepada pihak lain adalah dengan diwajibkannya peralihan hak dilakukan di hadapan Pejabat Pembuat Akta Tanah (PPAT) yang bertugas membuat Akta peralihan, yang membuktikan terjadinya perbuatan hukum pemindahan hak tersebut.

Pada kondisi masyarakat kaum adat baduy tersebut sudah tidak ada atau mereka melepaskan tanah ulayat nya sehingga menjadi tanah negara, tanah negara dapat dimohon oleh perseorangan/ Badan Hukum dan Tata cara peralihan hak atas tanah negara menjadi hak milik diatur dalam Peraturan Menteri Negara Agraria/ Kepala Badan Pertanahan Nasional Nomor 9 Tahun 1999, menurut pasal 9 ayat (1) jo. pasal 11 Permenag/KBPN Nomor 9/1999, Permohonan Hak Milik atas tanah negara diajukan secara tertulis kepada Menteri melalui Kepala Kantor Pertanahan yang daerah kerjanya meliputi letak tanah yang bersangkutan.

\section{Saran}

Pelaksanaan pendaftaran tanah sebagaimana disebutkan dalam Pasal 19 UUPA memberikan jaminan yuridis dan jaminan teknis dalam arti kepastian batasbatas fisiknya meliputi pengukuran dan pembukuan tanah, pendaftaran hak atas tanah dan peralihan hak-hak tersebut, pemberian Sertipikat tanda bukti hak tanah yang berlaku sebagai alat, pembuktian yang kuat sebaiknya diwujudkan demi terlaksananya perlindungan hukum dan kepastian hak atas tanah.

Keberadaan hak ulayat yang merupakan hak asli masyarakat Republik Indonesia yang telah ada sejak jaman dahulu kala harus dijaga kelestariannya 
secara bersama sama mengingat segala resiko kemajuan jaman tentunya dari sekarang kita mulai menerapkan pembatasan-pembatasannya secara konsisten mana tanah tanah yang telah mendapatkan perlindungan hukum adalah bagian tanah ulayat kaum adat jangan sampai atas nama modal pembangunan namun kita kehilangan harta pusaka.

\section{DAFTAR PUSTAKA}

Budi Harsono, Hukum Agraria Indonesia, Jilid 1 Edisi 2008, penerbit Djembatan

H.A.M Effendy, Pokok-Pokok Hukum Adat, Semarang, Duta Grafika, 1990

Jarot Widya Muliawan, Cara Mudah Pahami Pengadaan Tanah Untuk Pembangunan, Buku Litera Yogyakarta, 2016

Mukti Fajar ND. Yulianto Achmad, MH, Dualisme Penelitian Hukum Normatif \& Empiris, Yogyakarta, Pustaka Pelajar, 20104

Muchtar Wahid, Memaknai Kepastian Hukum Hak Milik Atas Tanah suatu analisa dengan Pendekatan Secara Normatif dan Sosiologis, Temaprinter Indoesia, Jakarta, 2008

Purnadi Purbacaraka dan A. Ridwan Halim, Sendi-Sendi Hukum Agraria, Jakarta, Ghalia Indonesia, 1983

Soerjono Soekamto \& Sri Mamuji, Penelitian Hukum Normative Suatu Tinjauan Singkat, Jakarta, Raja Grafindo Persada, 1985

Waskito, Hadi Arnowo, Cara praktis memahami bidang agrarian (pertanahan), Jakarta, PT.Media Adji, 2015 )

Wawancara dengan Supriyadi, S.Kom Kasubsi Kasubsi di BPN Lebak pada tangal 23 Desember 2016 